Prepared in cooperation with the City of Findlay, Ohio

\title{
Development of a Flood-Warning System and Flood-Inundation Mapping for the Blanchard River in Findlay, Ohio
}

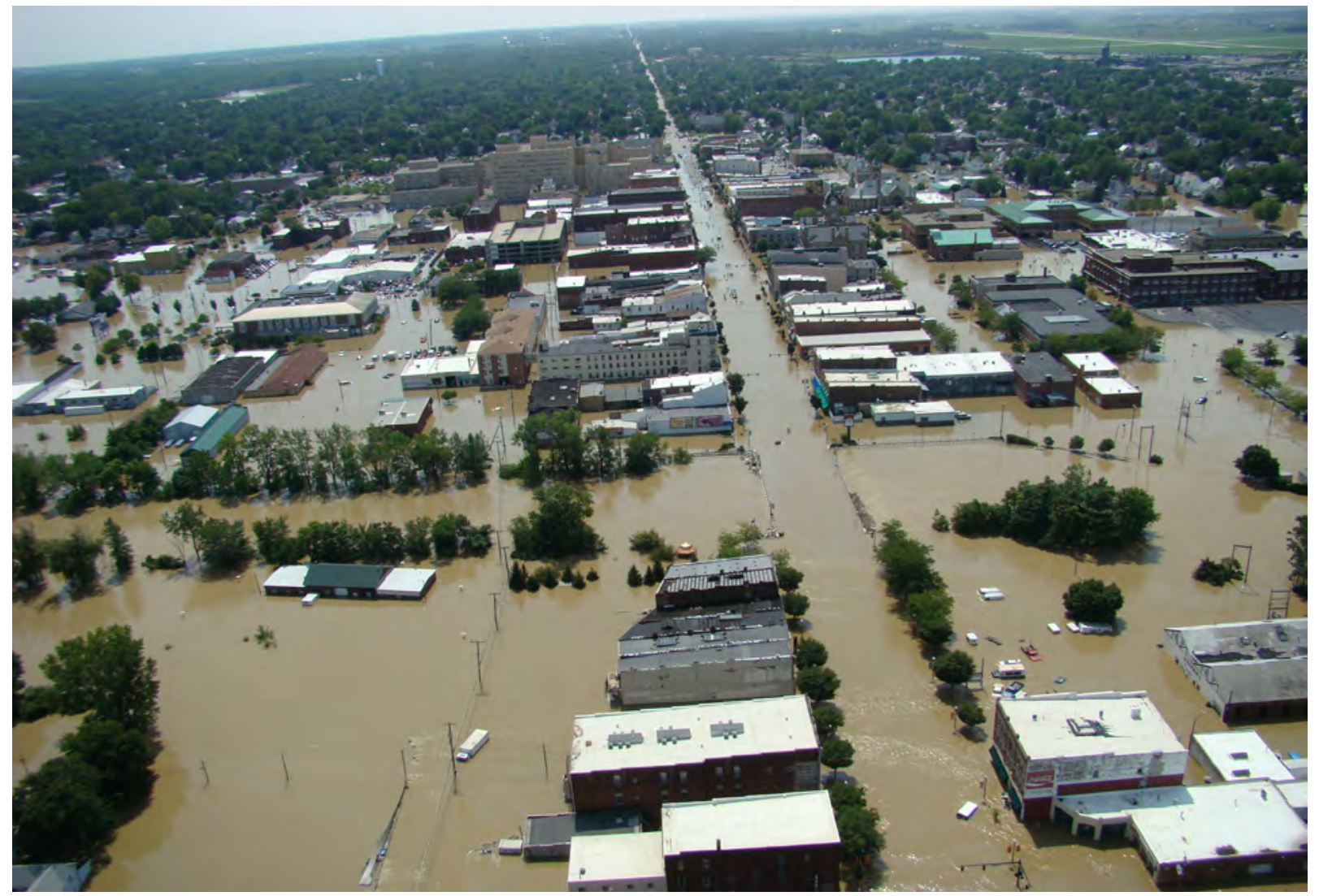

Scientific Investigations Report 2008-5234 
Cover: Floodwaters from the Blanchard River at the Main Street bridge over the Blanchard River in Findlay, Ohio (looking south). (Photo taken August 2007 by Mary Terry. Courtesy of Findlay Engineer's Office, reproduced with permission.) 


\section{Development of a Flood-Warning System and Flood-Inundation Mapping for the Blanchard River in Findlay, Ohio}

By Matthew T. Whitehead and Chad J. Ostheimer

Prepared in cooperation with the City of Findlay, Ohio

Scientific Investigations Report 2008-5234 


\section{U.S. Department of the Interior DIRK KEMPTHORNE, Secretary}

\section{U.S. Geological Survey \\ Mark D. Myers, Director}

\section{U.S. Geological Survey, Reston, Virginia: 2009}

For product and ordering information:

World Wide Web: http://www.usgs.gov/pubprod

Telephone: 1-888-ASK-USGS

For more information on the USGS--the Federal source for science about the Earth, its natural and living resources, natural hazards, and the environment:

World Wide Web: http://www.usgs.gov

Telephone: 1-888-ASK-USGS

Any use of trade, product, or firm names is for descriptive purposes only and does not imply endorsement by the U.S. Government.

Although this report is in the public domain, permission must be secured from the individual copyright owners to reproduce any copyrighted materials contained within this report. 


\section{Contents}

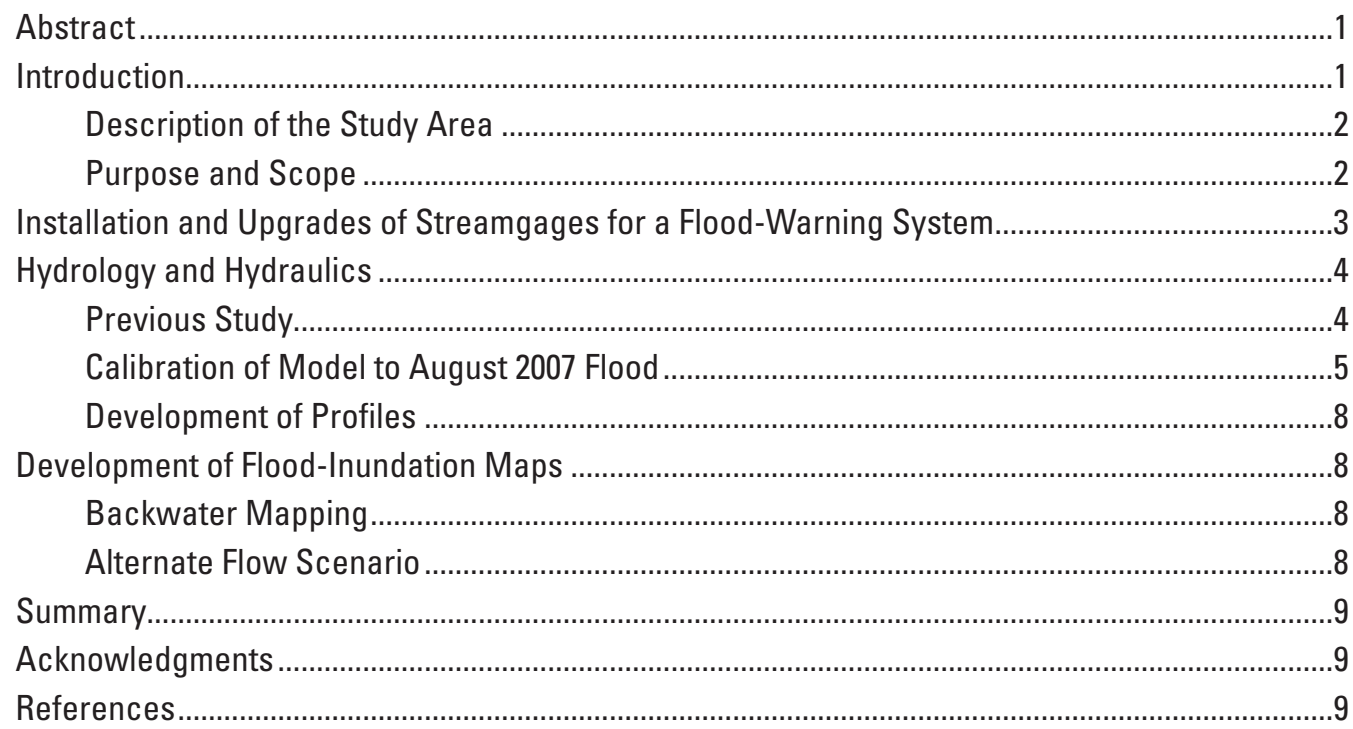

\section{Plates}

(Separate documents)

1. Flood-inundation areas for Blanchard River near Findlay, Ohio (station 04189000), for type-A and type-B flow distribution, stage of 11.00 feet

2. Flood-inundation areas for Blanchard River near Findlay, Ohio (station 04189000), for type-A and type-B flow distribution, stage of 12.00 feet

3. Flood-inundation areas for Blanchard River near Findlay, Ohio (station 04189000), for type-A and type-B flow distribution, stage of 13.00 feet

4. Flood-inundation areas for Blanchard River near Findlay, Ohio (station 04189000), for type-A and type-B flow distribution, stage of 14.00 feet

5. Flood-inundation areas for Blanchard River near Findlay, Ohio (station 04189000), for type-A and type-B flow distribution, stage of 15.00 feet

6. Flood-inundation areas for Blanchard River near Findlay, Ohio (station 04189000), for type-A and type-B flow distribution, stage of 15.50 feet

7. Flood-inundation areas for Blanchard River near Findlay, Ohio (station 04189000), for type-A and type-B flow distribution, stage of 16.00 feet

8. Flood-inundation areas for Blanchard River near Findlay, Ohio (station 04189000), for type-A and type-B flow distribution, stage of 16.50 feet

9. Flood-inundation areas for Blanchard River near Findlay, Ohio (station 04189000), for type-A and type-B flow distribution, stage of 17.00 feet

10. Flood-inundation areas for Blanchard River near Findlay, Ohio (station 04189000), for type-A and type-B flow distribution, stage of 17.50 feet

11. Flood-inundation areas for Blanchard River near Findlay, Ohio (station 04189000), for type-A and type-B flow distribution, stage of 18.46 feet 


\section{Figures}

1. Blanchard River watershed and the corporate boundary for Findlay, Ohio.

2. Locations of existing and new/reestablished USGS streamgages in the Findlay, Ohio, area. Information about and data from streamgages can be found at http://waterdata.usgs.gov/nwis.

\section{Tables}

1. Drainage areas of streamgages around Findlay, Ohio.

2. 100-year recurrence-interval peak-discharge estimates, drainage areas, and percentage of total discharge for selected locations on the Blanchard River (Federal Emergency Management Agency, 2006).

3. Comparison of hydraulic-model output and surveyed high-water-mark elevations from the August 22, 2007, flood on the Blanchard River. [ft, feet].

4. Stages (elevations), in feet, with corresponding discharge estimates at selected locations for the Blanchard River for selected HEC-RAS water-surface profiles for type-A scenarios.

\section{Conversion Factors}

\begin{tabular}{ccc}
\hline Multiply & By & To obtain \\
\hline & Length & \\
\hline foot $(\mathrm{ft})$ & 0.3048 & meter $(\mathrm{m})$ \\
mile $(\mathrm{mi})$ & 1.609 & kilometer $(\mathrm{km})$ \\
\hline & Area & \\
\hline square foot $\left(\mathrm{ft}^{2}\right)$ & 929.0 & square centimeter $\left(\mathrm{cm}^{2}\right)$ \\
square foot $\left(\mathrm{ft}^{2}\right)$ & 0.09290 & square meter $\left(\mathrm{m}^{2}\right)$ \\
\hline & Slope & \\
\hline Foot per mile $(\mathrm{ft} / \mathrm{mi})$ & 0.1894 & Meter per Kilometer $(\mathrm{m} / \mathrm{km})$ \\
\hline & Flow rate & \\
\hline cubic foot per second $\left(\mathrm{ft}^{3} / \mathrm{s}\right)$ & 0.02832 & cubic meter per second $\left(\mathrm{m}^{3} / \mathrm{s}\right)$
\end{tabular}

Vertical coordinate information is referenced to the North American Vertical Datum of 1988 (NAVD 88).

Horizontal coordinate information is referenced to the North American Datum of 1983 (NAD 83). 


\title{
Development of a Flood-Warning System and Flood-Inundation Mapping for the Blanchard River in Findlay, Ohio
}

\author{
By Matthew T. Whitehead and Chad J. Ostheimer
}

\section{Abstract}

Digital flood-inundation maps of the Blanchard River in Findlay, Ohio, were created by the U.S. Geological Survey (USGS) in cooperation with the City of Findlay, Ohio. The maps, which correspond to water levels at the USGS streamgage at Findlay (04189000), were provided to the National Weather Service (NWS) for incorporation into a Web-based flood-warning system that can be used in conjunction with NWS flood-forecast data to show areas of predicted flood inundation associated with forecasted flood-peak stages.

The USGS reestablished one streamgage and added another on the Blanchard River upstream of Findlay. Additionally, the USGS established one streamgage each on Eagle and Lye Creeks, tributaries to the Blanchard River. The streamgage sites were equipped with rain gages and multiple forms of telemetry. Data from these gages can be used by emergency management personnel to determine a course of action when flooding is imminent.

Flood profiles computed by means of a step-backwater model were prepared and calibrated to a recent flood with a return period exceeding 100 years. The hydraulic model was then used to determine water-surface-elevation profiles for 11 flood stages with corresponding streamflows ranging from approximately 2 to 100 years in recurrence interval. The simulated flood profiles were used in combination with digital elevation data to delineate the flood-inundation areas. Maps of Findlay showing flood-inundation areas overlain on digital orthophotographs are presented for the selected floods.

\section{Introduction}

Findlay is a medium-sized urban community $\left(28^{\text {th }}\right.$ largest city in Ohio) with an estimated population of 39,700 (U.S. Bureau of Census, 2006), yet it has more flood-insurance policies and claims than any other city within Ohio (Michael Gease, Ohio Department of Natural Resources, oral commun., August 2001). The Ohio Department of Natural Resources estimates that more than 1,100 flood-insurance policies are in effect in Findlay, with approximately $\$ 120$ million worth of property insured against flood damages.

Findlay has experienced severe flooding numerous times, with the four largest floods in the past hundred years occurring in 1913, 1959, 1981, and 2007. Damage costs (not adjusted for inflation) within Findlay for the 1959 flood were reported to be $\$ 700,000$ (Ohio Department of Natural Resources, Division of Water, 1959); for the 1981 flood, in excess of \$13 million (Webber, 1982); and for the most recent flood of 2007, more than $\$ 100$ million (National Oceanic and Atmospheric Administration, 2008). The majority of flood damages generally have occurred along the Blanchard River, Eagle Creek, and Lye Creek, all of which flow through the city. Floodplains within Findlay are moderately to highly developed with a mix of residential and commercial structures.

Before this study, Findlay officials relied on several information sources from which to make decisions on how to best alert the public and mitigate flood damages. One source is the Federal Emergency Management Agency (FEMA) Flood Insurance Study (FIS) for Findlay dated September 20, 2006 (Federal Emergency Management Agency, 2006). A second source of information is the USGS streamgage Blanchard River near Findlay (04189000), from which the water level (stage) can be accessed via telephone or the Web. The third source is the National Weather Service's (NWS) forecasts of peak stage.

The NWS has statutory responsibility for hydrologic forecasts throughout the Nation. Peak-stage forecasts are based partly on a network of precipitation gages and streamgages. In Ohio, the forecasts originate with the NWS River Forecast Center in Wilmington, Ohio, and warnings are issued to the public by regional NWS offices in Wilmington or Cleveland. Although one USGS streamgage and some precipitation gages were in place before this study, upgrades and additions to the streamflow network were expected to enhance the floodforecasting capabilities of the NWS for the Blanchard River in Findlay (Brian Astifan, National Weather Service, oral commun., April 2007). 


\section{Description of the Study Area}

Findlay is in northwest Ohio, in north-central Hancock County (fig 1). The headwaters of the Blanchard River originate in central Hardin County. The river flows generally north before turning west and bisecting the city. The Blanchard River is tributary to the Auglaize River, which eventually drains into Lake Erie. Two major tributaries to the Blanchard River that flow through Findlay are Eagle Creek and Lye Creek. Both tributaries flow generally north into the Blanchard River upstream from the downtown area. The basin terrain is relatively flat, and most of the basin is rural. The Blanchard River study reach has an average stream-channel slope of approximately $2.6 \mathrm{ft} / \mathrm{mi}$ and a total length of approximately $7.7 \mathrm{mi}$.

\section{Purpose and Scope}

The purpose of this report is to describe methods and results of hydrologic and hydraulic analyses of the Blanchard River within the corporate limits of Findlay, Ohio. A series of flood-inundation maps were developed for selected stages of the Blanchard River near Findlay streamgage.

Tasks specific to this study and discussed in this report were to (1) upgrade one existing streamgage, reestablish a second streamgage (Blanchard River above Findlay), and install three new streamgages; (2) install equipment to enable city officials to receive automated warnings about flood stage and/or predetermined rates of stage increase directly from the streamgages; and (3) estimate the areas of Findlay that will be flooded at selected stages and develop detailed floodinundation maps that can be overlain on existing orthographic images.

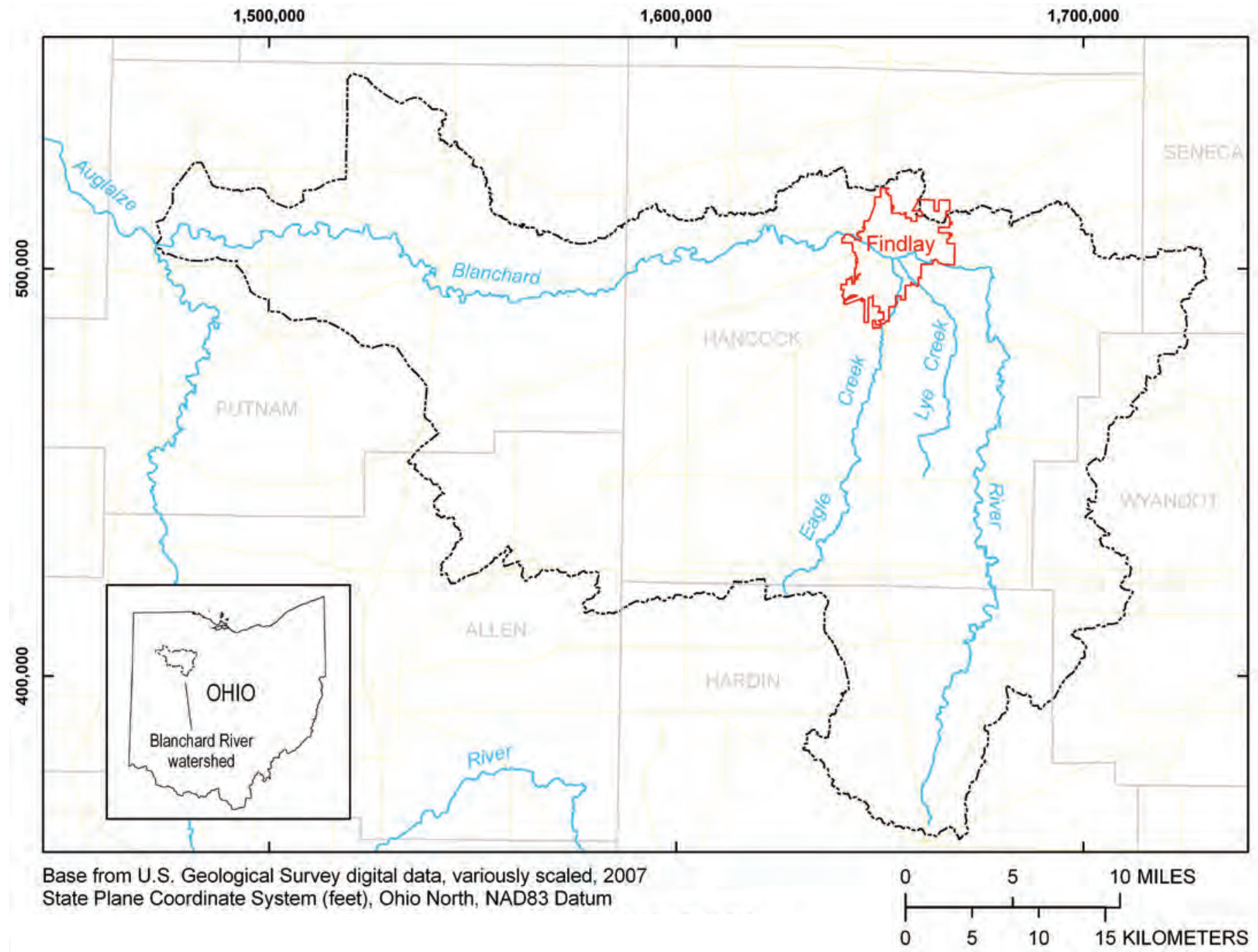

Figure 1. Blanchard River watershed and the corporate boundary for Findlay, Ohio. 
Installation and Upgrades of Streamgages for a Flood-Warning System

The USGS upgraded and/or installed a total of five streamgages (fig 2). The existing USGS streamgage Blanchard River near Findlay (04189000), in operation from 1924 to 1936 and continuously since 1941, was upgraded to improve data transmission capability. A discontinued streamgage, Blanchard River above Findlay (04188400), that operated from 1970 to 1972 was reestablished in September 2007. Three new streamgages-Blanchard River below Mt. Blanchard (04188337), Eagle Creek above Findlay (04188496), and Lye Creek above Findlay (04188433)—were installed in September 2007. All five streamgages were also equipped with rain gages.

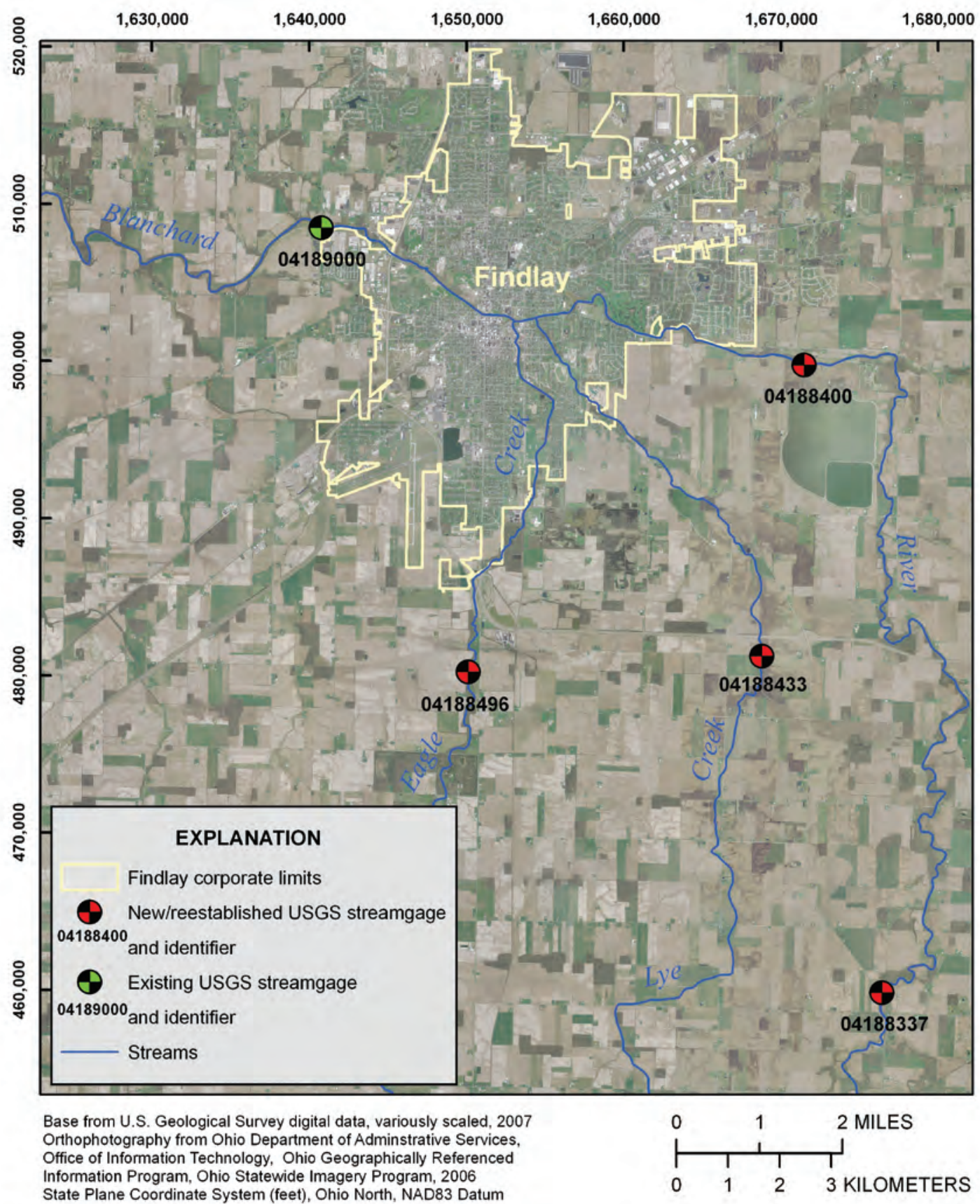

Figure 2. Locations of existing and new/reestablished USGS streamgages in the Findlay, Ohio, area. Information about and data from streamgages can be found at http://waterdata.usgs.gov/nwis.. 
All five gages contain a rain gage, a Geostationary Operational Environmental Satellite (GOES) transmitter, a Radio Frequency transmitter using the Automated Local Evaluation in Real Time (ALERT) protocol, and a voice modem. The ALERT radio network, also referred to as the STORMS program in Ohio, is operated by the Ohio Emergency Management Agency (OEMA) to collect rainfall data and current water-level conditions. The NWS uses the STORMS data to develop flood forecasts and issue flood watches and warnings. Local officials also can access the STORMS data to monitor rainfall data and current water-level conditions. The GOES data from the gages is collected by the USGS on a near realtime basis to monitor equipment performance and provide back-up data to the STORMS network. The voice modem provides dual capabilities of allowing city officials and others to call the gage to monitor current water-level conditions, and enabling the gage to call city officials to receive automated warnings about flood stage and/or predetermined rates of stage increase.

Locations of the newly installed streamgages were selected with input from the NWS and the City of Findlay with the goal of enhancing the NWS' peak-stage prediction capability for the Blanchard River near Findlay streamgage. Gage locations were selected based upon improving the distribution/coverage of the rain gage network within the Blanchard River watershed, and providing adequate early-warning information on changing upstream water-level conditions. The drainage areas for streamgage locations in and around Findlay range from 18.8 to $347 \mathrm{mi}^{2}$ (table 1).

Table 1. Drainage areas of streamgages around Findlay, Ohio.

\begin{tabular}{lcc}
\hline Streamgage & Site number & $\begin{array}{c}\text { Drainage area } \\
\left(\mathbf{m i}^{\mathbf{2}}\right)\end{array}$ \\
$\begin{array}{l}\text { Blanchard River near Findlay } \\
\text { Blanchard River above }\end{array}$ & 04189000 & 346 \\
$\quad$ Findlay & 04188400 & 233 \\
$\begin{array}{c}\text { Blanchard River below } \\
\quad \text { Mt. Blanchard }\end{array}$ & 04188337 & 141 \\
Eagle Creek above Findlay & 04188496 & 51.0 \\
Lye Creek above Findlay & 04188433 & 18.8 \\
\hline
\end{tabular}

\section{Hydrology and Hydraulics}

The hydraulic analyses were done with the U.S. Army Corps of Engineer's Hydrologic Engineering Center River Analysis System (HEC-RAS), version 3.1.1 (U.S. Army Corps of Engineers, 2002a). HEC-RAS is a one-dimensional stepbackwater model for computing water-surface profiles with steady-state (gradually varied) or unsteady-state flow computation options. HEC-RAS is accepted by FEMA for use in the National Flood Insurance Program (NFIP). All hydraulic analyses for this report were done with the steady-state flow computation option.

\section{Previous Study}

The current FIS for Findlay (Federal Emergency Management Agency, 2006) was completed by the USGS and delivered to FEMA in 2000. The 2006 FIS provides information on the 100-year-recurrence-interval flood and floodway profiles for the Blanchard River, Eagle Creek, and Lye Creek within the city limits of Findlay. Estimates of the peak discharges for the Blanchard River from the 2006 FIS (table 2) were based on historical data from the Blanchard River near Findlay streamgage (04189000) and weighted regression estimates as described by Koltun and Roberts (1990). These techniques were used to obtain peak-discharge estimates at three locations along the Blanchard River: (1) upstreamfrom Hancock County Road 140 (04189000, Blanchard River near Findlay), (2) upstream from Eagle Creek, and (3) upstream from Lye Creek. Locations and regression estimates from the 2006 FIS are listed in table 2.

\section{Calibration of Model to August 2007 Flood}

On August 22, 2007, a near-record-peak flood occurred at the Blanchard River near Findlay streamgage. The measured peak discharge and stage for this event were $14,500 \mathrm{ft}^{3} / \mathrm{s}$ and 18.46, respectively. The peak flood of record occurred in March 1913 and had an estimated discharge and stage of $22,000 \mathrm{ft}^{3} / \mathrm{s}$ and 18.50 , respectively. As part of the documentation of the August 2007 flood event, high-water marks along the Blanchard River were surveyed throughout Findlay.

The base HEC-RAS model for this report was the same used for the 2006 FIS for Findlay, and was subsequently altered to incorporate physical changes to the streambed and overbank areas since the 2006 FIS. Physical changes included, but were not limited to, (1) removal of one low-head dam below Cory Street, and (2) construction of two new low-head dams, one above Cory Street and one above Blanchard Street.

The USGS calibrated the HEC-RAS model to match the high-water-mark profile of the 2007 flood by adjusting roughness coefficients and contraction/expansion losses. Discharges for locations upstream from station 04189000 on the Blanchard River (above Eagle Creek and above Lye Creek) were computed with the assumption that the percentage contribution to the total flow was the same as that assumed for the 2006 FIS (table 2).

The results of the model calibration are listed in table 3. Because the HEC-RAS model was taken from the 2006 FIS, most of the high-water marks from the 2007 FIS were not colocated with the model cross sections. To compare the modeled results to the high-water-mark profile, the water-surface elevations at the locations of the high-water marks were determined by linear interpolation from water-surface elevations at the nearest upstream and downstream modeled cross sections. 
Table 2. 100-year recurrence-interval peak-discharge estimates, drainage areas, and percentage of total discharge for selected locations on the Blanchard River (Federal Emergency Management Agency, 2006).

$\left[\mathrm{mi}^{2}\right.$, square miles; $\mathrm{ft}^{3} / \mathrm{s}$, cubic feet per second $]$

\section{Locations on the Blanchard River}

Upstream from County Road 140

Upstream from Eagle Creek

Upstream from Lye Creek
Drainage area $\left(\mathrm{mi}^{2}\right)$

246

9,830

69.7
Discharge estimate $\left(\mathrm{ft}^{3} / \mathrm{s}\right)$

14,100

10,900

77.3

\section{Percentage of total discharge}

100

274

Table 3. Comparison of hydraulic-model output and surveyed high-water-mark elevations from the August 22, 2007, flood on the Blanchard River.

[ft, feet]

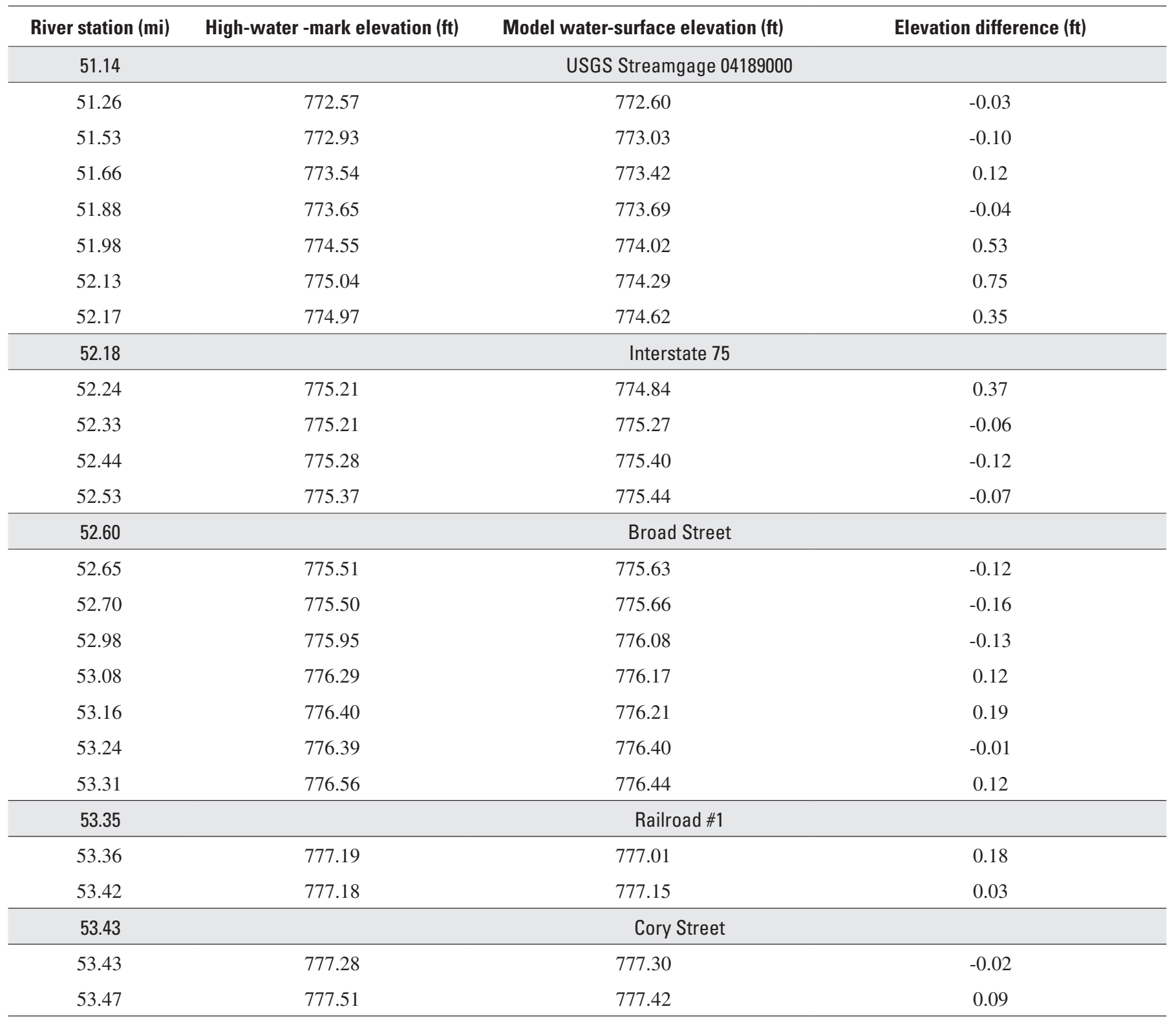


Table 3. Comparison of hydraulic-model output and surveyed high-water-mark elevations from the August 22, 2007, flood on the Blanchard River. [ft, feet]-Continued.

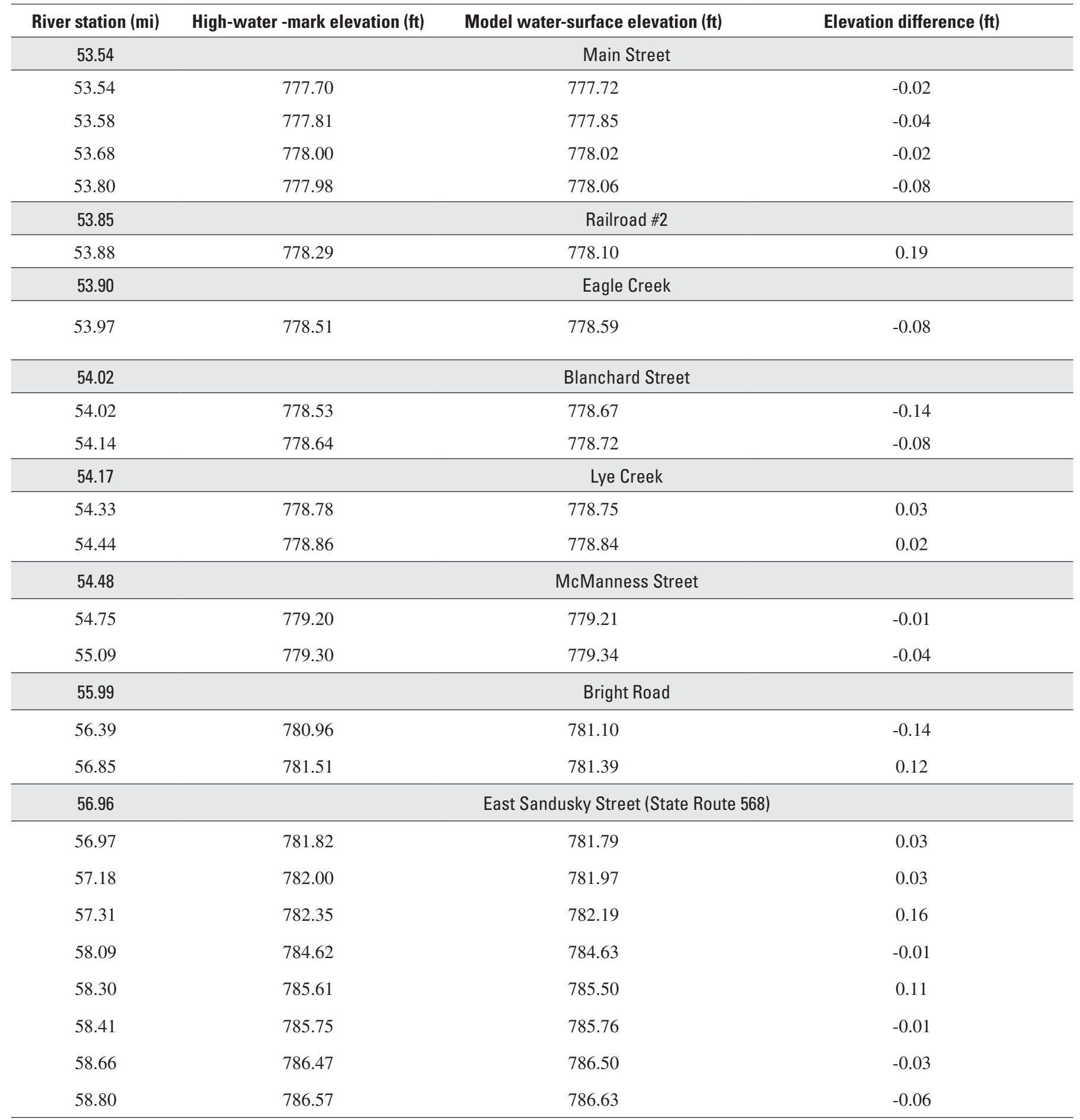


The modeled and surveyed water-surface elevations are in close agreement with the exception of the section between river stations 51.98 and 52.24, inclusive, where the high-water marks were higher than the modeled water-surface elevations. The high-water marks for this section were all rated "good" or "excellent" and were independently surveyed. The topography in this reach did not appear to have been significantly altered since the publication of the 2006 FIS. As a result, this discrepancy could not be explained but may have been due to a temporary obstruction in the stream. Given that 1) the reach is relatively short (approximately 1,300 ft) and undeveloped, and 2) agreement is close between the surveyed and modeled water-surface elevations immediately upstream and downstream from this reach, the model was judged to be acceptable.

\section{Development of Profiles}

Profiles were developed for a total of 11 stages (11.00, $12.00,13.00,14.00,15.00,15.50,16.00,16.50,17.00,17.50$, and $18.46 \mathrm{ft}$ ) at the Blanchard River near Findlay streamgage. Discharges corresponding to the various stages were obtained from the most current stage-streamflow relation at USGS streamgage 04189000 (rating number 31), which was the effective relation at the time of this report.

As mentioned previously, discharges for all profiles at locations upstream from station 04189000 on the Blanchard River (above Eagle Creek and above Lye Creek) were computed with the assumption that the percentage contribution to the total flow was the same as that assumed for the 2006 FIS (table 2). For this report, this type of flow-distribution scenario is referred to as the "type-A" scenario. A summary of discharge estimates for the type-A scenario for the 11 modeled stages is given in table 4 .

Table 4. Stages (elevations), in feet, with corresponding discharge estimates at selected locations for the Blanchard River for selected HEC-RAS water-surface profiles for type-A scenarios.

\begin{tabular}{|c|c|c|c|c|c|c|c|c|c|c|c|}
\hline \multicolumn{12}{|c|}{$\begin{array}{l}\text { Stage, in feet above gage datum } \\
\text { (Elevation, in feet, NAVD 88) }\end{array}$} \\
\hline Location & $\begin{array}{c}11.00 \\
(764.76)\end{array}$ & $\begin{array}{c}12.00 \\
(765.76)\end{array}$ & $\begin{array}{c}13.00 \\
(766.76)\end{array}$ & $\begin{array}{c}14.00 \\
(767.76)\end{array}$ & $\begin{array}{c}15.00 \\
(768.76)\end{array}$ & $\begin{array}{c}15.50 \\
(769.26)\end{array}$ & $\begin{array}{c}16.00 \\
(769.76)\end{array}$ & $\begin{array}{c}16.50 \\
(770.26)\end{array}$ & $\begin{array}{c}17.00 \\
(770.76)\end{array}$ & $\begin{array}{c}17.50 \\
(771.26)\end{array}$ & $\begin{array}{c}18.46 \\
(772.22)\end{array}$ \\
\hline $\begin{array}{l}\text { Upstream from } \\
\text { County Road } 140\end{array}$ & 5,010 & 5,850 & 6,750 & 7,700 & 8,710 & 9,230 & 9,770 & 10,500 & 11,400 & 12400 & 14,500 \\
\hline $\begin{array}{l}\text { Upstream from } \\
\text { Eagle Creek }\end{array}$ & 3,870 & 4,520 & 5,220 & 5,950 & 6,730 & 7,130 & 7,550 & 8,120 & 8,810 & 9,590 & 11,200 \\
\hline $\begin{array}{l}\text { Upstream from } \\
\text { Lye Creek }\end{array}$ & 3,490 & 4,080 & 4,700 & 5,370 & 6,070 & 6,430 & 6,810 & 7,320 & 7,950 & 8,640 & 10,100 \\
\hline
\end{tabular}




\section{Development of Flood-Inundation Maps Alternate Flow Scenario}

The USGS used the same high-definition digital topographic data that were used for the 2006 FIS to develop floodinundation maps for this report. Based upon National Standard for Spatial Data Accuracy standards, the digital mapping data for the study met the horizontal and vertical criteria for Flood Insurance Rate Maps (Federal Emergency Management Agency, 2003) as established by the Federal Geographic Data Committee (Federal Geographic Data Committee, 1998).

Estimated flood-inundation boundaries for the type-A scenarios were initially developed with HEC-GeoRAS software (U.S. Army Corps of Engineers, 2002b). HEC-GeoRAS is a set of procedures, tools and utilities for processing geospatial data in ArcGIS using a graphical user interface. The interface allows the preparation of geometric data for import into HEC-RAS and processes simulation results exported from HEC-RAS (U.S. Army Corps of Engineers, 2002b). USGS personnel then modified the HEC-GeoRAS results to ensure a logical transition of the boundary between modeled cross sections relative to the contour data for the land surface. The type-A scenario flood-inundation boundaries were then overlain onto digital georeferenced aerial photography from the Ohio Statewide Imagery Program (Ohio Department of Administrative Services, 2007) that was flown in 2007. The resulting estimated flood-inundation boundaries for the type-A scenario for the 11 stages can be found at the Web site http://pubs.usgs.gov/sir/2008/5234./

\section{Backwater Mapping}

The extent to which backwater from the Blanchard River extends up a tributary varies for each profile. Backwater from the Blanchard River is shown extending up tributaries to the point at which the water-surface elevation of the Blanchard River at the confluence would be contained within the banks of the tributary without consideration for any increase in the water surface that may result from water flowing in the tributary.
The percentage of streamflow contributed by Eagle and Lye Creeks flow to the mainstem of the Blanchard River is variable and cannot be known in advance of a flood. Streamflow contributions are affected by antecedent conditions and the areal distribution of rainfall (and possibly snowpack) for a given storm event. As a result, for a given streamflow at the streamgage on the Blanchard River near Findlay, the amount of streamflow in the mainstem above a tributary can vary from zero (if all streamflow at the confluence of the tributary and mainstem comes from the tributary) to the approximate streamflow at the gage (if no streamflow is contributed by the tributary). In most cases, the streamflow will be between these two extremes.

In order to account for the uncertainty in the distribution of flow between the Blanchard River and its two largest tributaries within Findlay, Eagle and Lye Creeks, an alternateflow-scenario model was developed for each modeled stage. This alternate flow scenario is based on the assumption of no tributary input to the mainstem and for this report is referred to as the "type-B" scenario. The type-B scenario model for each stage was developed by maintaining the full discharge in the mainstem over the entire modeled reach. Although this flowdistribution scenario is unlikely, it results in a consistent and conservative estimate of the maximum flooding that would be likely to occur for a given stage.

The flood-inundation boundary for the type-B scenario for each stage was initially mapped with HEC-GeoRAS software (U.S. Army Corps of Engineers, 2002b). Given that the type-B scenario for each stage is likely to provide a conservative estimate for the flood-inundation boundary, no attempt was made to smooth the flood-inundation boundary produced by HEC-GeoRAS. The type-B scenario flood-inundation boundary for a given stage developed by HEC-GeoRAS was merged with the type-A scenario flood-inundation boundary of the same stage to ensure that the type-B scenario floodinundation boundary extended at least as far out as the type-A scenario flood-inundation boundary.

Additional edits made to the type-B scenario flood-inundation boundaries were to remove any disconnected pockets of water and to ensure the type-B scenario flood-inundation boundary for a given stage extended at least as far as the typeB scenario flood-inundation boundary for the next lower stage. The resulting estimated flood-inundation boundaries for the type-B and type-A scenarios for the 11 stages can be found at the Web site http://pubs.usgs.gov/sir/2008/5234/. 


\section{Summary}

A flood-warning system was developed for the Findlay area by upgrading and adding to the existing streamgage network, estimating flood-inundation boundaries corresponding to selected flood stages, and installing equipment that enables emergency-response personnel and the public to quickly and easily access the predicted flood-inundation information.

The existing streamgage network was enhanced by (1) improved data transmittal to the Blanchard River near Findlay streamgage; (2) reestablishing a previously discontinued streamgage on the Blanchard River; and (3) establishing three new streamgages, one on the Blanchard River and one each on Eagle and Lye Creeks. All five streamgages were also equipped with rain gages. The streamflow and precipitation data from these gages will be used by the NWS to improve the peak-stage predictions for the Blanchard River near Findlay streamgage. In addition, Findlay officials can now receive automated warnings about the current stage from the Blanchard River near Findlay streamgage via a dedicated phone line and callout capabilities.

Expected flood-inundation boundaries were delineated within Findlay for 11 stages at the Blanchard River near Findlay, Ohio, streamgage (04189000) by means of a step-backwater model. The flood-inundation boundaries were overlain on digital georeferenced aerial photography. The 11 profiles range in stage from approximately the 2-year-recurrence-interval flood to the 100-year-recurrence-interval flood.

Real-time streamgage information, flood-forecast predictions, and flood-inundation mapping corresponding to the flood forecasts can be accessed on various Web sites hosted by the USGS, City of Findlay, and the NWS. The increased availability of streamflow data, the enhanced flood-prediction capability, and public access to the data will improve the ability of city officials to assess flood conditions, take appropriate steps to protect life and property, and reduce flood damages.

\section{Acknowledgments}

The authors thank the many local, state, and Federal agencies that have cooperated in the funding for the operation and maintenance of the stream gages throughout the country. We especially thank the Findlay Flood Task Force, Findlay Engineering Department, and the NWS for their support and cooperation throughout the study. Individual thanks go to Mike Sobczyk, former City of Findlay Service Director, and Steve Ferryman, ODNR Division of Water, for their initial coordination efforts for this report.

\section{References}

Federal Emergency Management Agency, 2006, Flood Insurance Study, City of Findlay, Ohio, Hancock County, Community Number 390244, September 20, 2006, [variously paged]

Federal Emergency Management Agency, 1995, Guidelines and specifications for study contractors [variously paged]

Federal Geographic Data Committee, 1998, Geospatial Positioning Accuracy Standards, Part 3: National Standard for Spatial Data Accuracy (FGDC-STD-007.3-1998), 28 p.

Koltun, G.F. and Roberts, J.W., 1990, U.S. Geological Survey Water-Resources Investigations Report 89-4126, Techniques for estimating flood-peak discharges of rural, unregulated streams in Ohio, $68 \mathrm{p}$.

National Oceanic and Atmospheric Administration, 2008, Storm events for Ohio, accessed on January 11, 2008, at http://www4.ncdc.noaa.gov/cgi-win/wwcgi. dll?wwevent $\sim$ storms

Ohio Department of Administrative Services, Office of Information Technology_Ohio Geographically Referenced Information Program, 2007, Ohio Statewide Imagery Program, Hancock County, accessed March 13, 2008, at http://ogrip.oit.ohio.gov/

Ohio Department of Natural Resources, Division of Water, 1959, Preliminary report of floods in Ohio-January, 1959; February, 1959: p. 26

U.S. Army Corps of Engineers, Hydrologic Engineering Center, 2002a, HEC-RAS River Analysis System, hydraulic reference manual, Version 3.1, [variously paged]

U.S. Army Corps of Engineers, Hydrologic Engineering Center, 2002b, HEC-GeoRAS, accessed on November 27, 2007, at URL http://www.hec.usace.army.mil/software/hec-ras/ hec-georas.html

U. S. Bureau of the Census, 2006, State population datasetsPopulation, population change and estimated components of population change: April 1, 2000 to July 1, 2006 (NST_EST2006_ALLDATA), accessed on November 30, 2007, at URL http://www.census.gov/popest/datasets.html

Webber, E.E., 1982, Flood of June 13-15, 1981, in the Blanchard River Basin, northwestern Ohio: U.S. Geological Survey Water-Resources Investigations Report 82-4044, $32 \mathrm{p}$. 


